\section{Bred fremstilling av psykiatri}

Simonsen E, Møhl B, red

Grundbog i psykiatri

959 s, tab, ill. København: Hans Reitzels

Forlag, 2010. Pris DKK 598

ISBN 978-87-412-5025-0

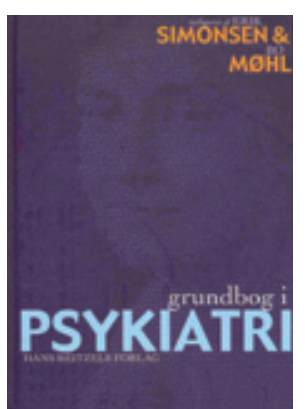

Målgruppen er «personer, der skal tilegne seg faget, men også som en oppdatering for professionelle». Medisinstudenter eller leger nevnes ikke spesielt, men boken er åpenbart også myntet på den medisinske profe-

sjonen. Den er bygd opp omkring seks hovedområder: Først er det en innledning der man bekjentgjør og redegjør for et biopsykososialt ståsted med personligheten som dreiepunkt. Så følger de fem neste områdene: den psykiatriske undersøkelsen, kliniske beskrivelser av psykiatriske lidelser, behandlingsmetoder, spesielle pasientpopulasjoner og forholdet mellom psykiatri og samfunn. I alt er det 51 kapitler som alle innledes med en klinisk vignett egnet til å sensibilisere leseren på tema. De fleste kapitlene avsluttes med en oversikt over anvendt litteratur og anbefalt videre lesning. Hvert kapittel har en til to forfattere med i alt 38 bidragsytere. Boken har likevel fătt et enhetlig preg. Språket er lettlest dansk med en naturlig bruk av bokser og figurer, noe som letter lesningen. Utformingen er relativt kompakt, men likevel delikat.

Forfatterne pretenderer å sette det enkelte menneske i sentrum - i motsetning til et reduksjonistisk menneskesyn der tanker, følelser og handlinger reduseres til kjemiske prosesser, og der den kunnskap vi har på gruppenivå, i for stor grad får dominere vår tilnærming til den enkelte. Perspektivet er tidsriktig, men det halter noe i kapitlet om det psykiatriske intervjuet, der man søker å personkarakterisere ulike diagnostiske grupper. Det er unødvendig og kan virke stigmatiserende.

De to første avsnittene (ca. 200 sider) favner bredt og gir et godt grunnlag for kritisk forståelse av de mer klinisk orienterte avsnittene. Forfatterne tenderer til å vektlegge psykodynamisk tilnærming, men man presenterer alle de vanligste psykoterapeutiske retningene der det er relevant, og i et eget kapittel om psykoterapi drøfter man om det er spesifikke eller uspesifikke faktorer som virker. «Personlighetsforstyrrelser» drøftes også som meningsfullt begrep. Disse eksemplene har jeg tatt med for å illustrere at man legger opp til en reflekterende holdning til et fag der kunnskapsgrunnlaget ennå kan være tynt. Det hadde vært å ønske samme type tilnærming til bipolar lidelse, men her redegjør man kun for type I og II uten å drøfte et utvidet bipolart spekter. Det burde vært gjort. En annen åpenbar mangel er at det ikke er et eget kapittel om forebyggende psykiatri. Sentrale områder som krise- og katastrofepsykiatri og tidlig intervensjon ved psykose blir heller ikke behandlet. Videre nevner man psykoedukasjon og pårørendesamarbeid kun sporadisk.

Alt $i$ alt presenterer man imidlertid faget imponerende bredt, og boken vil kunne konkurrere godt med tilsvarende bøker og gå inn som standard læreverk. Den er også egnet som oppslagsverk.

Terje Øiesvold

Bodø

\section{Grundbog om personlighedspsykiatri}

Karterud S, Wilberg T, Urnes $\emptyset$. Personlighetspsykiatri

538 s, tab, ill. Oslo: Gyldendal Akademisk, 2010. Pris NOK 685

ISBN 978-82-05-39210-6

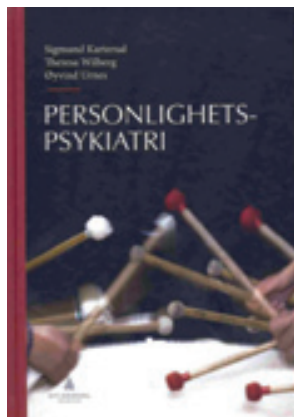

Denne nye lærebog er skrevet af tre overlæger fra Avdeling for Personlighetspsykiatri ved universitetssygehuset i Oslo, Ullevål. De henvender sig primært til psykiatere og kliniske psykologer og den prægraduate undervisning $\mathrm{i}$ disse fagområder, men definerer sig på omslaget med en appel til en langt bredere læserkreds. Bogen er delt op i fem dele: en bred indføring i det bio-psyko-sociale grundlag for personlighedspatologi, en grundig gennemgang af DSM personlighedsforstyrrelserne (rig på referencer!), personlighedspatologi ved symptomtilstande, en glimrende oversigt over norskoversatte instrumenter til personlighedsudredning samt anvisning af evidensbaserede og ligeværdige behandlingsmetoder af patienter med personlighedsforstyrrelser. Bogen adskiller sig fra andre kliniske lærebøger ved at man giver forholdsvis meget plads til den grundlæggende indføring $\mathrm{i}$ teori og begrebsafklaring, et «patchwork» på hele 15 kapitler, som også indbefatter refleksioner om betydning af evolutionsteori og idehistorie for personlighedspsykiatri samt et forsøg på integration af de mange fragmenter. Bedst gennemarbejdet står et fint illustreret kapitel om neurobiologien bag personlighedspatologi. I kapitel om syndromer savner man en gennemgang af personlighedspatologi ved andre tilstande, f.eks. somatisering, generaliseret angst, panikangst, psykogene psykoser («den præmorbide psyke») og tilbagevendende depressioner.

Man retter sig primært mod behandling i sygehusvæsenet, men man kunne med fordel have mere fokus på de retspsykiatriske problemstillinger, den vanskelige patient $\mathrm{i}$ almen praksis og i liaisonpsykiatri samt i socialvæsenet, hvor mange patienter med manglende sociale kompetencer forbliver udiagnosticeret og dermed aldrig får et behandlingstilbud.

Overlægerne gør sig på baggrund af deres grundige videnskabelige unders $\varnothing$ gelser og lang klinisk erfaring også nogle overvejelser om hvilke ændringer, der kunne være ønskelige i DSM-V og ICD-11.

Dette er en fin dokumentation for det gennem tiderne stærke norske bidrag til international forskning af personlighedsforstyrrelser, som for mange år siden blev initieret af især af Per Vaglum og Svenn Torgersen.

Titlen er næppe set før og er vel fra forfatternes side et ønske om at markere et paradigmeskift, så klinikere bedre kan få øje på «the person behind the illness» og værdien af den nødvendige udredning for personlighedspatologi, også ved symptomtilstande.

Bogen anbefales meget varmt til klinikere, som ønsker en opdatering af, hvad en særskilt akse II i DSM-III tilbage fra 1980 gennem 30 år har affødt af forskning og klinisk erfaring i behandling af personligheds- 
forstyrrelser og ikke mindst deres sammenhæng med symptomtilstande. Det er prisværdigt, at lægegruppen ved Avdeling for Personlighetspsykiatri fortsat insisterer på at være toneangivende inden for området personlighedsforstyrrelser, som mange steder er «tabt» til psykologgruppen. Bogen leverer fin dokumentation for, hvordan lægens specielle indsigt i psykopatologi, neurobiologi, komorbiditet og kunnen i såvel medicinsk som psykoterapeutisk behandling gør det nødvendigt at fastholde fokus på personlighedspatologi i både den prægraduate og postgraduate undervisning.

\section{Erik Simonsen}

Psykiatrisk Forskningsenhed

Region Sjælland

Danmark

\section{Oppskrytt bok}

Johannisson K

\section{Melankolske rom}

Om angst, lede og sårbarhet gjennom tidene. 289 s. Oslo: Cappelen Damm, 2010.

Pris NOK 349

ISBN 978-82-02-32188-8

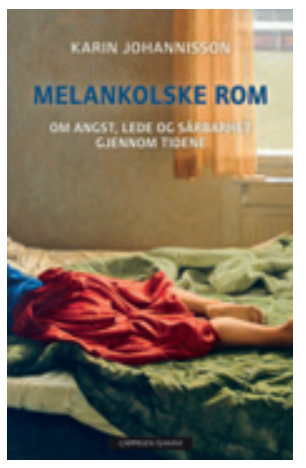

Karin Johannisson er professor i idéhistorie ved Uppsala Universitet og har skrevet en rekke artikler og bøker der hun bl.a. behandler legekunst og psykiske plager i historisk perspektiv. Anmeldelser i avisene har vært påfallende

positive. Målgruppen er, som for mange andre bøker fra hennes hånd, åpenbart den opplyste allmennheten.

I psykiatrien snakker vi lite om melankoli i dag. Før brukte man gjerne dette begrepet om alvorlige, dype depresjoner. I dag anvender man helst begrepet depresjon om nedstemthet som kan ha forskjellig alvorlighetsgrad, fra de lettere tristhetstilstandene til de mest alvorlige tilstandene som sågar kan gå over i psykose.

Det er ikke lett å vite hva forfatteren mener med melankoli. Hun forsøker aldri å definere begrepet, men som hun sier, kan melankoli dukke opp i en rekke sammenhenger: «Først og fremst som benevnelse på en følelse og en sinnstilstand. Men også som navn på det å stå utenfor, eller på en spesiell form for kollektivt minne, eller på en desillusjonert moderne identitet, eller kanskje på en apokalyptisk undergangsstemning». Ser man det, ikke småtterier. Selv vil hun studere melankoli som følelsestilstand, sier hun, måtene å være melan- kolsk på, hvordan den er blitt følt og uttrykt. Ingen lett oppgave når hun ikke vet hva hun mener med melankoli. Av tittelen får man inntrykk av at hun vil inkludere både angst, lede og sårbarhet i sin melankoli.

Men det er ikke bare begrepet som er uklart og byr på problemer. Hennes valg av sykehistorier mener hun dekker noe tidstypisk. Hvordan kan hun vite det? Hun tar gjerne utgangspunkt $\mathrm{i}$ kjente personers psykiske lidelser som hun omtaler og spekulerer rundt. Den første er Caspar Barlaeus (1584-1648) som var professor i filosofi i Amsterdam og leilighetsdikter. I løpet av sitt liv ble han rammet av klar depresjon minst fire ganger. Pussig nok trekker forfatteren inn den moderne utbrenthetstematikken i diskusjonen her. Hun skriver om litteraten Samuel Johnson (1709-84) som har fått mange diagnoser. Han var ingen typisk melankoliker, men personlighetsmessig en avvikende tvangskarakter. Vi hører om Esaias Tegnér (1782-1846), Sveriges store nasjonalskald, som både ble professor i gresk og biskop, og som gjennom sitt voksne liv stadig var plaget med stemningssvingninger. Her blir hun opptatt av Tegnérs pasjon for god mat og drikke og kroppens nytelser. Særlig stor plass ofrer forfatteren på Max Weber (1864-1920), den berømte sosiologen som ble professor i Berlin bare 29 år gammel, men som i flere år var ute av arbeid pga. alvorlig depresjon. Som mange deprimerte var han plaget av søvnløshet, men i tillegg hadde han nattlige pollusjoner som hans kone mente var nøkkelen til mannens lidelse.

Johannisson er belest, og det er interessant hva hun forteller om kjente personers liv og psykiske plager, men mange ting sauses sammen på en merkelig måte; angst, fobier, lede, søvnløshet, tretthet. Vi får høre at den kreative er sårbar (sensibel, nervøs), den intellektuelt samtidskritiske er melankolsk, og bare den som arbeider engasjert med hjernen, blir utbrent.

Forfatterens hovedanliggende har vært, sier hun, å forstå hvordan melankolien taler, og hvordan denne talen påvirkes av tiden og rommet. Det har hun selvsagt ikke maktet, og hvordan skulle hun klare det. For ikke vet vi hva hun forstår med melankoli, og ikke har hun uselekterte data om denne mystiske lidelsen.

\section{Einar Kringlen}

Psykiatrisk institutt

Universitetet i Oslo

\section{Kvalitativt om unge med rus og psykiske problemer}

Randby M.

\section{Å leve med alvorlige}

rus- og psykiatriproblemer

På vei mot en bedre hverdag. 138 s, ill.

Oslo: Kommuneforlaget, 2010. Pris NOK 258

ISBN 978-82-446-2010-9

Margrethe Randby har utdanning innen sosialt arbeid og har skrevet en bok på bakgrunn av sin masteroppgave. I boken presenterer hun en kvalitativ studie av fem unge mennesker som sliter med psykiske problemer og har et problemfylt forhold til rusmidler. Noen er ute av rusbruken, mens noen fortsetter å arbeide med problemet. Hennes fokus har vært på informantenes positive opplevelser og deres mer konstruktive erfaringer. Hva er det som hjelper? Hva kan gi håp? Det er med andre ord en bok som skal (og kan) stimulere til et mer fortrøstningsfullt syn på fremtiden for en gruppe som så altfor ofte problemforklares.

Med utgangspunkt i Maslows behovspyramide, Løgstrups etikk og Prochaskas og DiClementes endringshjul forteller hun historier som det er noe å lære av. Det narrative står sentralt. Men teorien trekkes også inn der det er relevant. Hun makter å forene ulike teoretiske retninger; psykologiske, medisinske (om enn i noe mindre grad) og sosiale, og hun legger som sagt vekt på det positive, blant annet finner man et avsnitt om fysisk aktivitet og trening.

Så flott at noen leverer en god masteroppgave. Så flott at man tar på seg arbeidet med å lage en bok av det. Så flott at man klarer å løfte det fra oppgave til innlevering til noe som andre kan lære av. Og dette har Randby langt på vei klart. Skulle man kritisere noe, så måtte det være at hun av og til ikke har gått riktig langt nok i å forene de teoretiske bitene med bokens budskap om endring der pasientene står. Jeg synes ikke at Randby er pedagogisk nok i presentasjonen av betydningen av f.eks. Maslows behovspyramide. Språket er av og til for omstendelig. Hvorfor skrive: «i vedkommendes subjektive opplevelse av egen virkelighet» (s. 54). Smør på flesk (og vel så det)? Noen slike språklige overflødigheter kunne Kommuneforlagets språkkonsulent hjulpet til med å fjerne. Innimellom synes jeg også Randby kunne fått hjelp til å bli enda mer konkret på hva hun ønsket å formidle.

Men disse tingene forhindrer ikke at Randbys bok ut fra en helhetsvurdering holder mål. Boken vil passe for folk som arbeider i rusmiddelfeltet og i psykisk helsevern. Den kan passe som pensumbok innen bachelorog mastergradsutdanning for disse feltene.

Jørgen G. Bramness

Senter for rus- og avhengighetsforskning Universitetet i Oslo 